\title{
New Reconds of Aleuroclava (Hemiptera: Aleyrodidae) from Korea
}

\author{
Soo-Jung Suh \\ Yeongnam Regional Office, National Plant Quarantine Service, Korea \\ 가루이과(노린재목) 한국미기록 2종에 대한 보고 \\ 서수정 \\ 국립식물검역원 영남지원
}

\begin{abstract}
Aleuroclava aucubae (Kuwana) and Aleuroclava euryae (Kuwana) are newly recorded in the Korean fauna of whiteflies (Aleyrodidae). A key to species of Aleuroclava is also provided with illustrative photographs.

Key wonds: Aleuroclava aucubae, Aleuroclava euryae, New Records, Aleyrodidae, Korea

초 록: 가루이 Aleuroclava aucubae (Kuwana)와 Aleuroclava euryae (Kuwana) 2종을 처음으로 국내분포로 보고하고, 한국산 Aleuroclava의 종 동정에 필요한 검색표 및 사진자료롤 함께 기재하였다.
\end{abstract}

검색어: Aleuroclava aucubae, Aleuroclava euryae, 미기록중, 가루이과, 한국

The whitefly genus Aleuroclava is known to occur almost worldwide and is represented by 108 described species (Evans, 2008). In Korea three species of this genus have been previously documented; namely Aleuroclava hikosanensis (Takahashi), Aleuroclava magnoliae (Takahashi), and Aleuroclava montanus (Takahashi) (Paik and Park, 1963; Lee et al., 2005; Suh, 2009). One of these the buxus whitefly (A. hikosanensis), was reported in Korea (Paik and Park, 1963); however, no material of $A$. hikosanensis from this collection was examined by the author. Recently, Suh and Hodges (2008) reported $A$. hikosanensis from Korea based on newly collected specimens; however, through a re-examination of the specimens by the senior author and comparing them to specimens of $A$. hikosansensis and $A$. euryae deposited in the USNM, it was determined that they had been misidentified and were actually Aleuroclava euryae (Kuwana). The shape of the puparium of some specimens of $A$. euryae collected in Korea is very similar to that of $A$. hikosa-

*Corresponding author: suhsj97(anpqs.go.kr Received September 25 2009; revised March 8 2010; accepted December 42009 nensis, but the latter species can be distinguished by the narrow submarginal area and by the dorsal disk which has some minute circular pores scattered, very densely with numerous rather large black granules except on the marginal narrow area and the median area of each abdominal segment (Takahashi, 1952).

Two species, Aleuroclava aucubae (Kuwana) and Aleuroclava euryae (Kuwana), are newly reported from the Republic of Korea. A key to the Korean Aleuroclava species and photographs of the two species are provided. An asterisk(*) is used to indicate a new host or distribution record.

\section{Aleuroclava aucubae (Kuwana) 1911}

(Figs. 1-3)

\section{Material examined.}

Korea. Gyeongsangnamdo: Daesin-dong, 9 puparia (on the underside of leaf), on Stephanandra incisa, 13.xii.2007 (S.J. Suh); Jinju arboretum, 1 puparium (on the underside of leaf), on Pittosporum tobira, 18.iii.2008 (S.J. Suh); 
Oe-do, 16 puparia (on the underside of leaf), on Pittosponum tobira, 5.xi.2008 (S.J. Suh). Jejudo: Halla arboretum, 41 puparia (on the underside of leaf), on Citrus sp., 3.x.2003 (S.J. Suh); same data, except for 4 puparia (on the underside of leaf), on Cudrania tricuspidata; same data, except for 9 puparia (on the underside of leaf), on Lagerstroemia indica; same data, except for 4 puparia (on the underside of leaf), on Prumus persica; same data, except for 28 puparia (on the underside of leaf), on Morus bombycis; Halla arboretum, 12 puparia (on the underside of leaf), on Morus bombycis, 5.x.2003 (S.J. Suh); same data, except for 1 puparium (on the underside of leaf), on Prunus buergeriana; same data, except for 4 puparia (on the underside of leaf), on Prunus yedoensis; same data, except for 6 puparia (on the underside of leaf), on Ulmus davidiana; Halla arboretum, 6 puparia (on the underside of leaf), on Morus bombycis, 19.x.2005 (S.J. Suh); same data, except for 1 puparium (on the underside of leaf), on Prunus persica; Hallim park, 1 puparium (on the underside of leaf), on Citrus junos, 4.x.2003 (S.J. Suh); same data, except for 4 puparia (on the underside of leaf), on Citrus sp.; same data, except for 48 puparia (on the underside of leaf), on Morus bomycis; same data, except for 3 puparia (on the underside of leaf), on Rosa sp.; same data, except for 4 puparia (on the underside of leaf), on Pyracantha sp.; Seogwipo-si, 20 puparia, on Citrus unshiu, 24.v.2000 (M.L. Lee).

\section{Hosts.}

Aquifoliaceae: Ilex crenata; Araliaceae: Hedera japonica; Caprifoliaceae: Lonicera gracillipes; Cornaceae: Aucuba japonica; Ericaceae: Pieris japonica; Flacourtiaceae: Myroxylon japonicum; Juglandaceae: Juglans sieboldiana; Lauraceae: Cinnamomum sp., Litsea glauca; Moraceae: *Cudrania tricuspidata, Ficus erecta, Morus alba, *Morus bombycis; Myricaceae: Myrica sp.; Oleaceae: Ligustrum japonicum; Pittosporaceae: Pittosporum tobira; Lythraceae: *Lagerstroemia indica, Rosaceae: Kerria japonica; Rosaceae: Neillia uekii, *Prunus buergeriana, Prunus mume, *Prumus persica, *Prunus yedoensis, *Pyracantha sp., Rhaphiolepis umbellate, *Rosa sp., *Stephanandra incisa; Rubiaceae: Paederia sp; Rutaceae: *Citrus junos, Citrus sp., *Citrus unshiu, Phellodendron lavallei, Zanthoxylum piperitum; Theaceae: Eurya japonica; Styracaceae: Styrax japonica; Ulmaceae: Aphananthe aspera, *Ulmus davidiana (Kuwana, 1911; Takahashi, 1952; Miyatake, 1980; Evans, 2008).

\section{Distribution.}

China, Japan, *Korea, and USA(California).

\section{Comments.}

This species is fairly common in the southern area of Korea.

\section{Aleuroclava euryae (Kuwana) 1911}

(Figs. 4-6)

Aleuroclava hikosanensis (Takahashi), Suh \& Hodges, 2008: 127 (misidentification).

\section{Material examined.}

Korea. Gyeonggido: Seodun-dong, 7 puparia, on Buxus microphylla, 10.v.1996 (O.J. Kim); same data, except for 17 puparia, 24.ix.1998 (M.L. Lee). Gyeongsangnamdo: Pyochungsa, 11 puparia (on the underside of leaf), on Buxus microphylla, 28.iv.2006 (S.J. Suh). Jejudo: Seongpanak, 104 puparia, on Buxus microphylla, 24.v.2000 (M.L. Lee); same data, except for 25 puparia (on the underside of leaf), 20.x.2005 (S.J. Suh); same data, except for 15 puparia (on the underside of leaf), on Ilex crenata, 14.iv.2007 (S.J. Suh).

\section{Hosts.}

Aquifoliaceae: Ilex crenata, Ilex pedunculosa; Buxaceae: *Buxus microphylla; Ericaceae: Pieris japonica, Rhododendron sp.; Lauraceae: Lindera sp., Neolitsea sericea, undetermined genus of Lauraceae; Magnoliaceae: Michelia compressa; Theaceae: Eurya japonica, Eurya ochnacea; Trochodendraceae: Trochodendron aralioides (Kuwana, 1911; Takahashi, 1952; Miyatake, 1980; Evans, 2008).

\section{Distribution}

Japan and *Korea. 


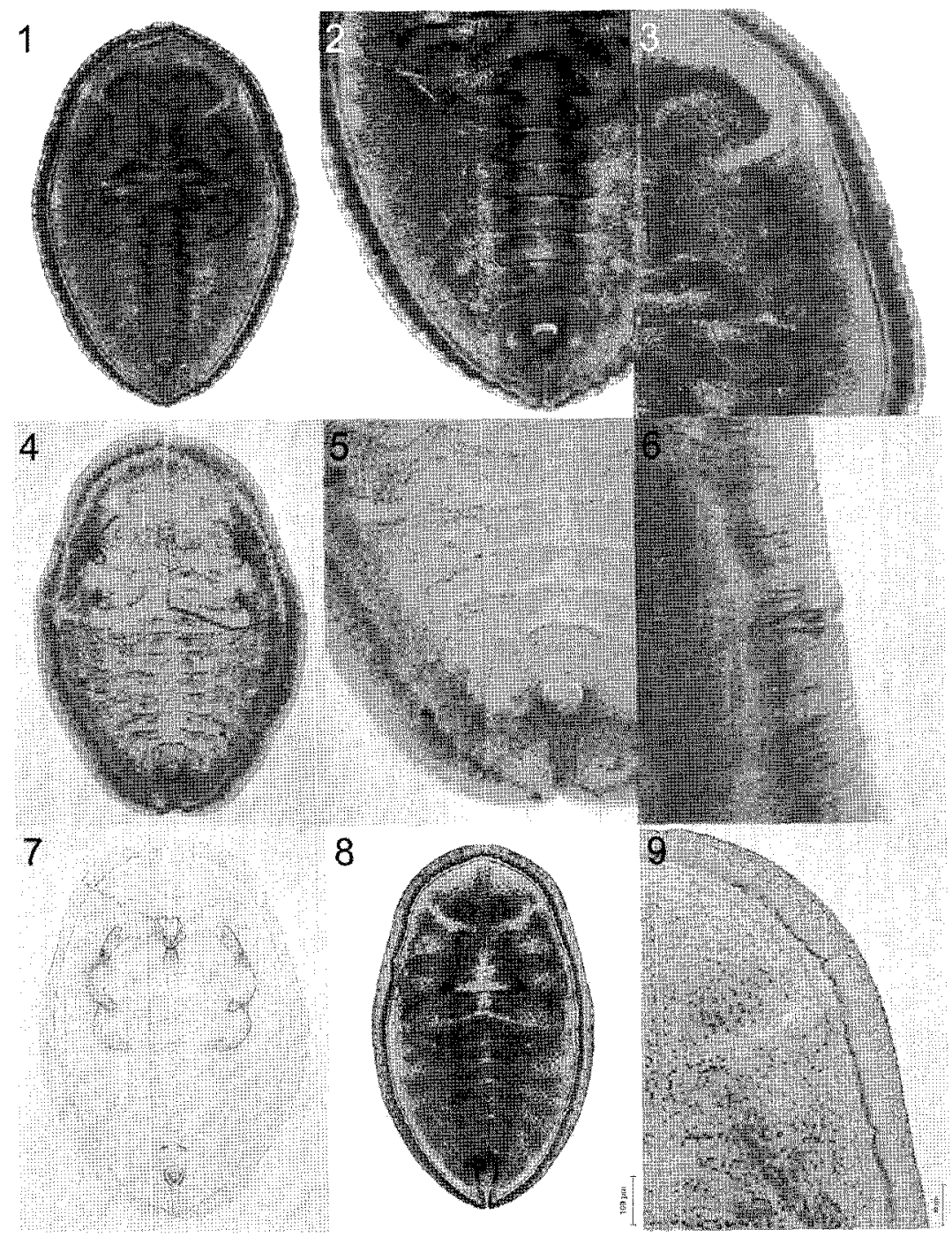

Figs. 1-3. Aleuroclava aucubae (Kuwana): (1) puparium, (2) abdomen, (3) thoracic tracheal cleft. Figs.4-6. Aleuroclava euryae (Kuwana): (4) puparium, (5) abdomen and vasifom orifice, (6) thoracic tracheal cleft. Fig. 7. Aleuroclava magnoliae (Takahashi), puparium. Figs. 8-9. Aleuroclava montanus (Takahashi): (8) puparium, (9) cephalothoracic margin.

\section{Comments.}

This species is fairly common near Tokyo, Japan; however, according to Takahashi (1952), is less frequently encountered than A. aucubae.

\section{Key to Aleuroclava species (puparium) in Korea}

1. Puparium white

…. Aleuroclava magnoliae (Takahashi) (Fig. 7)

1b. Puparium black
2. Abdomen much constricted at the posterior half; eyespots pale, oblique slender rod-shaped; scattered minute circular pores present on dorsum

Aleuroclava hikosanensis (Takahashi)

2b. Abdomen shape and eyespots not as above; minute circular or arrow-shaped pores present or absent on

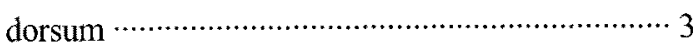

3 . With thoracic tracheal clefts at the margin of cephalo-

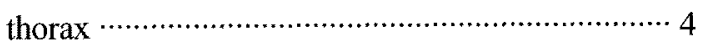

$3 \mathrm{~b}$. Without thoracic tracheal clefts at the margin of cephalothorax

... Aleuroclava montanus (Takahashi) (Figs. 8-9) 
4. Abdomen with a very sclerotised median rhachis without lateral arms; thoracic tracheal clefts distinct with its fold represented by an oval or semi-circularshaped area extending into the submarginal area ....... Aleuroclava aucubae (Kuwana) (Figs. 1-3)

4b. Abdomen without a sclerotised median rhachis, usually with a slightly elevated median area with lateral arms; thoracic tracheal clefts small and not fold as above

Aleuroclava euryae (Kuwana) (Figs. 4-6)

\section{Acknowledgements}

I would like to thank Drs. Jon Martin (Natural History Museum, UK) and Greg Evans (USDA/Animal and Plant Health Inspection, USA) for confirming the identification of 2 species added in this paper. I also thank Dr. Greg Evans for his useful editorial contributions to this manuscript.

\section{Literature Cited}

Evans, G.A. 2008. The whiteflies (Hemiptera: Aleyrodidae) of the world and their host plants and natural enemies (http:// www.sel.barc.usda.gov/whitefly/wfframe.htm).

Kuwana, I. 1911. The whiteflies of Japan. Pomona College J. Entomol. 3: 620-627.

Lee, M.L., S.J. Suh, G. Hodges and M. Carver. 2005. Eight species of whiteflies (Homoptera: Aleyrodidae) newly recorded from Korea. Insecta Mundi. 19(3): 159-166.

Miyatake, Y., 1980. A list of the whiteflies of Japan with their host plant and distribution data (Homoptera: Aleyrodidae). Rostria 32: 291-330.

Paik, W.H. and C.S. Park. 1963. A list of pests in Korea. 129pp. Pumin Publishing Co.

Suh, S.J. 2009. New records of Korean whiteflies (Hemiptera: Aleyrodidae). J. Asia Pac. Entomol. 12: 45-49.

Suh, S.J. and G.S. Hodges. 2008. Key to the Korean species of whiteflies (Hemiptera: Aleyrodidae). J. Asia Pac. Entomol. 11: 123-131.

Takahashi, R., 1952. Aleurotuberculatus and Parabemisia of Japan (Aleyrodidae, Homoptera). Misc. Rep. Res. Inst. Nat. Resources. Tokyo. 25: 17-24. 